\title{
Analysis and Research on Influence Factors of Anaerobic Ammonia Oxidizing Bacterial Activity
}

Tian Xiaoyan*, Feng Ke

School of Municipal and Environmental Engineering ,Jilin Jianzhu University, Changchun 130118, PR china

\begin{abstract}
This paper probes into the anaerobic ammonia oxidation startup phase and the concentration of nitrate nitrogen, $\mathrm{PH}$ and temperature on the start stage, and the effects of nitrogen, the results show that:(1) The nitrate nitrogen concentration and enrichment of anaerobic ammonia oxidation bacteria biomass has certain relevance, and nitrate nitrogen concentration increases to a certain concentration, the biomass of anaerobic ammonia oxidation bacteria concentration and the activity of anaerobic ammonia oxidation bacteria has certain inhibition;(2) Anaerobic ammonia oxidation bacteria within the reactor at the optimum $\mathrm{pH}$ value, the reaction rate is the largest, and biological activity also relatively stable; Deviation from the optimum $\mathrm{pH}$ value, reaction rate and its stability are affected;(3) Under the condition of low temperature restrain the activity of anaerobic ammonia oxidation bacteria, when the temperature rose from $15{ }^{\circ} \mathrm{C}$ to $35{ }^{\circ} \mathrm{C}$, anaerobic ammonia oxidation reaction rate showed a trend of first increased and then declined slightly, the temperature is about $30{ }^{\circ} \mathrm{C}$, the anaerobic ammonia oxidation reaction rate is the fastest.
\end{abstract}

\section{Introduction}

With the continuous development of modern biological technology, biological denitrification new theory and new technology emerge in endlessly, such as SHARON (Single reactor for high ammonium removal over nitrite) process, OLAND process (oxygen limited sutrification and DE itrification), SND (Simultaneous nitrication and denitrification), $\mathrm{A}_{2} \mathrm{O}$ process, SBR process, etc. [1]. But no matter what form of processing technology, based on the mechanism of biological denitrification and if get good denitrification effect, will be influenced by many factors, namely, water way, operation condition, reaction temperature, $\mathrm{DO}$, sludge age, $\mathrm{NO}_{3}{ }^{-}-\mathrm{N}$ concentration, ratio of feed nutrition [2-11]. This article is based on the An/OSBR technology of anaerobic ammonia oxidation on which the nitrate nitrogen concentration, reaction temperature and $\mathrm{pH}$ were discussed.

\section{Materials and Methods}

\subsection{Reactor system}

The An/OSBR process is showed in Fig1, its methods of operation in Fig2, Laboratory scale reactor was made of acrylic sheet, high $40 \mathrm{~cm}$, diameter $10 \mathrm{~cm}$, mud pipe is at the bottom. Porous stones were used for micro-porosity aerator with an air blower aeration, the reactor equipped with stirrer to keep the uniformity of water and sludge, during un-aerated state or little aeration, temperature controller to hold at $25^{\circ} \mathrm{C}$, DO, ORP and $\mathrm{pH}$ transducer to monitor the changes of DO, ORP and $\mathrm{pH}$. The sludge age was controlled about 10 days by discharging excess sludge for the reactor system, so MLSS was maintained about $2500 \mathrm{mg} / \mathrm{L}$.

\subsection{Feed and Inoculation sludge}

The feed was imitated domestic sewage, in influent beer and peptone were added for $\mathrm{COD}, \mathrm{NaHCO} 3$ to $\mathrm{pH}$, $\mathrm{NH} 4 \mathrm{Cl}$ for ammonia nitrogen,KH2PO4 for phosphate, $\mathrm{MgSO} 4$ and $\mathrm{CaCl} 2$ for $\mathrm{Mg} 2+$ and $\mathrm{Ca} 2+$, Adding trace element solution to meet the requirements of microbial growth and reproduction of activated sludge. In the process of the experiment, according to different test requirements, adjust the water content in time., the application is shown in table 1 .

Inoculation sludge came from the secondary sedimentation tank of MUCT, which is laboratory scale reactor too. The mixed home sewage was treated in reactor from October 2007. The reactor reached steady state to remove phosphorus after ten weeks operation, it was the time to measure sample.

\subsection{Test items and Analytical Methods}

Wastewaterr sample for dynamic studies were collected from centrifuge supernatant after Centrifugation Determination, COD of sampl concentration was measured by Molybdenum Antimony Spectrophotometer Method, $\mathrm{NH}_{4}{ }^{+}-\mathrm{N}$ concentration was measured by Determination of Ammonia Nitrogen, $\mathrm{NO}_{3}{ }^{-} \mathrm{N}$ by $\mathrm{N}$-(1-naphthy1)-ethylene diamine spectrophometor, MLSS by Filter Weight Method, SVI was measured according to standard method (SV30/MLSS).

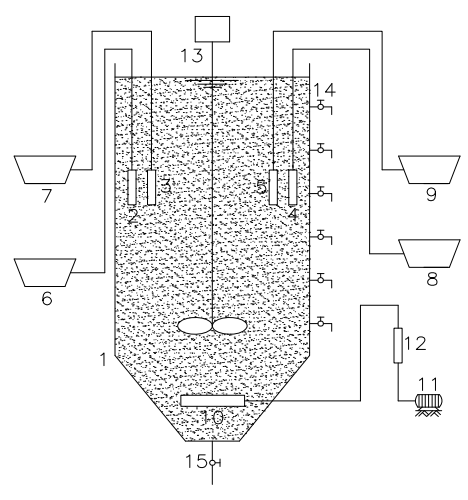

\footnotetext{
Fig.1.The configuration of An/OSBR process

1-Reactor;2- $\mathrm{pH}$ transducer;3-DO transducer;4-ORP

transducer;5-temperature transducer;6- $\mathrm{pH}$ cryoscope;7-DO

cryoscope;8-ORP cryoscope;9—-temperature controller;10-Aeration

head;11 - air compressor; 12 -flow

meter;13-mixing;14—sampling;15—outlet of sludge
} 
Table 1 Components of simulational wastewater and feature of water quality

\begin{tabular}{|c|c|c|c|c|c|}
\hline \multicolumn{2}{|c|}{$\begin{array}{c}\text { Components of simulational } \\
\text { wastewater }\end{array}$} & \multicolumn{2}{|c|}{ Minor factor } & \multicolumn{2}{|c|}{ Quota of water quality } \\
\hline $\begin{array}{c}\text { Medical } \\
\text { preparation }\end{array}$ & $\begin{array}{c}\text { Throws the } \\
\text { increment } / g \cdot L^{-1}\end{array}$ & compose & concentration/g. $\mathbf{L}^{-1}$ & item & concentration $/ \mathbf{m g} \cdot \mathrm{L}^{-1}$ \\
\hline $\begin{array}{c}\text { Beer } \\
\text { wastewater }\end{array}$ & $1.5 \sim 3.5 \mathrm{~mL} / \mathrm{L}$ & $\mathrm{FeCl}_{3}$ & 0.9 & COD & $200 \sim 500$ \\
\hline peptone & 0.1 & $\mathrm{H}_{3} \mathrm{BO}_{4}$ & 0.15 & BOD & $118 \sim 315$ \\
\hline $\mathrm{NH}_{4} \mathrm{Cl}$ & 0.1 & $\mathrm{CoCl}_{2} \cdot 7 \mathrm{H} 2 \mathrm{O}$ & 0.15 & TN & $23.5 \pm 1$ \\
\hline $\mathrm{KH}_{2} \mathrm{PO}_{4}$ & 0.044 & $\mathrm{CuSO}_{4} \cdot 5 \mathrm{H} 2 \mathrm{O}$ & 0.03 & $\mathrm{NH}_{4}^{+}-\mathrm{N}$ & $21.1 \pm 0.8$ \\
\hline $\mathrm{NaHCO}_{3}$ & $0.16 \sim 0.8$ & KI & 0.18 & $\mathrm{NO}_{3}^{-}-\mathrm{N}$ & $<1$ \\
\hline $\mathrm{CaCl}_{2}$ & 0.01 & $\mathrm{MnCl}_{2} \cdot 4 \mathrm{H} 2 \mathrm{O}$ & 0.06 & $\mathrm{NO}_{2}^{-}-\mathrm{N}$ & $<1$ \\
\hline $\mathrm{MgSO}_{4}$ & 0.05 & $\mathrm{Na}_{2} \mathrm{Mp} \cdot 2 \mathrm{H} 2 \mathrm{O}$ & 0.06 & TP & $10.0 \pm 0.5$ \\
\hline $\begin{array}{l}\text { Minor fator } \\
\text { liqud }\end{array}$ & $0.6 \mathrm{~mL} / \mathrm{L}$ & $\mathrm{ZnSO}_{4} \cdot 7 \mathrm{H} 2 \mathrm{O}$ & 0.12 & $\mathrm{pH}$ & $6.9 \sim 7.1$ \\
\hline
\end{tabular}

\subsection{Results and Discussion}

From figure 2, anaerobic ammonia oxidation bacteria of nitrite is sensitive, the nitrate nitrogen concentration is lower on the activity of anaerobic ammonia oxidation bacteria effect is not obvious, with the increase of the nitrate concentration, When the concentration of nitrate nitrogen is $1.9 \mathrm{mmol} / \mathrm{L}$, it began to show the inhibition of anaerobic ammonia oxidation reaction ; When the concentration of nitrate nitrogen is $4.9 \mathrm{mmol} / \mathrm{L}$, the activity of anaerobic ammonia oxidation bacteria almost lost. Analysis of the reason may be increased with the increase of the nitrate nitrogen concentration of the denitrification reaction intermediates material is reduced, and then make the cause of the anaerobic ammonia oxidation reduction bacteria activity.then make the cause of the anaerobic ammonia oxidation reduction bacteria activity.

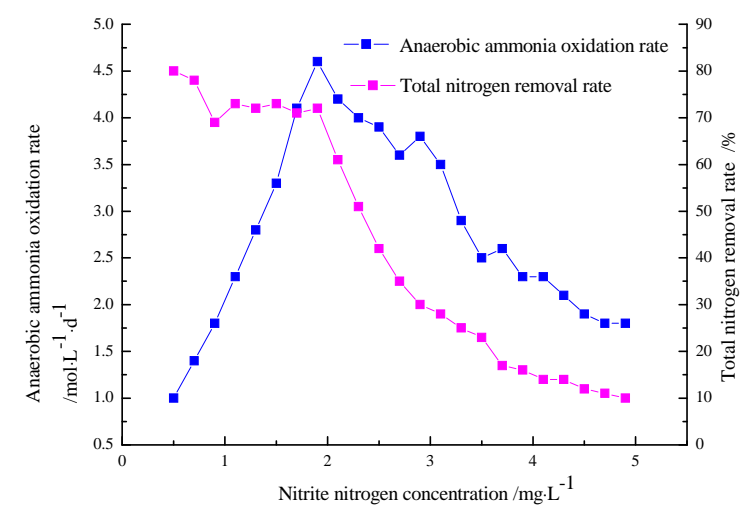

Fig 2 The curve of the relation of the sub-nitrate concentration and the ammonia oxidation rate of F1

From figure 3, when the temperature has risen from 1 $0{ }^{\circ} \mathrm{C}$ to $45{ }^{\circ} \mathrm{C}$, anaerobic ammonia oxidation $\mathrm{TN}$ removal rate showed a trend of increase before falling. When the $t$ emperature has risen from $10{ }^{\circ} \mathrm{C}$ to $38{ }^{\circ} \mathrm{C}$, anaerobic amm onia oxidation rate continuously improve, when the temp erature was $38{ }^{\circ} \mathrm{C}$, the maximum conversion rate, when $\mathrm{t}$ he temperature more than $38{ }^{\circ} \mathrm{C}$, the anaerobic ammonia oxidation rate falling; When the temperature reaches 38 ${ }^{\circ} \mathrm{C}$, loss of anaerobic ammonia oxidation rate. When the te mperature reaches $38{ }^{\circ} \mathrm{C}$, loss of anaerobic ammonia oxid ation rate.

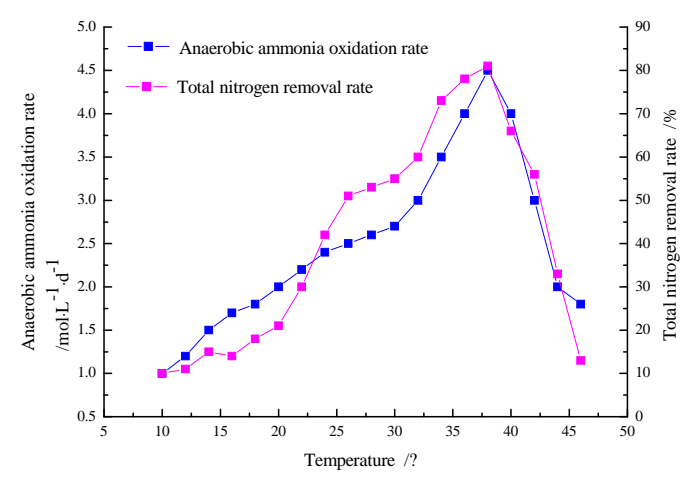

Fig 3 The curve of the relation of the temperature and the ammonia oxidation rate of $\mathrm{F} 1$

From figure 4, the activity of anaerobic ammonia oxidation bacteria is very sensitive to the change of $\mathrm{pH}$, when the $\mathrm{pH}$ is less than 6 , anaerobic ammonia oxidation will not occur, when the $\mathrm{pH}>9$, anaerobic ammonia oxidation also not going to happen, in pH6 9 interval, TN removal rate showed a trend of increase before falling. When the $\mathrm{pH}=8.0$, $\mathrm{TN}$ reached maximum conversion rate.

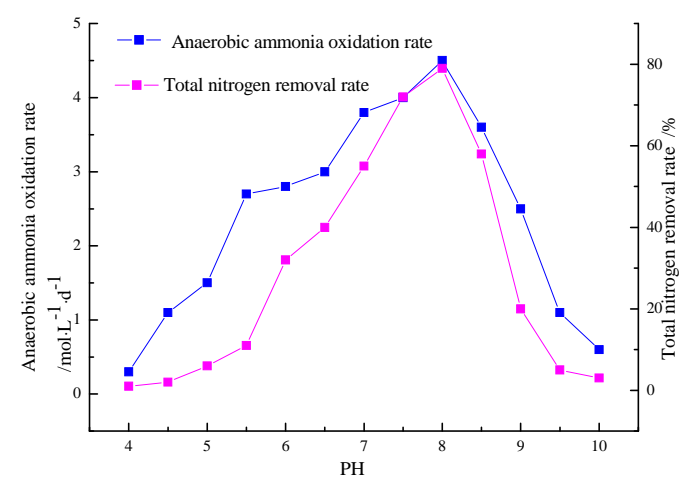

Fig 4 The curve of the relation of the $\mathrm{PH}$ and the ammonia oxidation rate of $\mathrm{F} 1$ 


\section{Summary}

(1) With the increase of the nitrate concentration, anaerobic ammonia oxidation reaction rate must change rule, when the concentration of nitrate nitrogen tendency from $0.5 \mathrm{mmol} / \mathrm{L}$ to $1.9 \mathrm{mmol} / \mathrm{L}$, and the increase of nitrate nitrogen concentration is beneficial to accelerate the anaerobic ammonia oxidation reaction rate, in the land of the nitrate nitrogen concentration tendency for $1.9 \mathrm{mmol} / \mathrm{L}$ reaction rate reached the maximum value. Then, with the increase of the nitrate nitrogen concentration anaerobic ammonia oxidation reaction rate declines, shows a certain inhibitory

effect.

(2) The $\mathrm{pH}$ of the influence factors of anaerobic ammonia oxidation reaction rate is very important, the $\mathrm{pH}$ is too lo $\mathrm{w}$, the influence of oxygen enrichment of ammonia oxidi zing bacteria and grow. $\mathrm{PH}$ is too high, also can reduce th e activity of anaerobic ammonia oxidation bacteria, in the $\mathrm{pH}=6 \sim 9$ range change, when $\mathrm{pH}=8.0$, TN reached $\mathrm{m}$ aximum conversion rate.

(3) Temperature is one of the important factors that affect anaerobic ammonia oxidation bacteria. Under the conditi on of low temperature, the activity of anaerobic ammonia oxidation bacteria is reduced, affect the active transport $r$ ate of nutrients; Under the condition of high temperature, the structure of anaerobic ammonia oxidation bacteria wi ll the degeneration occurs, even lead to the death of anaer obic ammonia oxidation bacteria. The optimum temperat ure for $38{ }^{\circ} \mathrm{C}$, achieve maximum conversion rate.

\section{References}

[1] Kenen J.Getal.Ecology of nitrfication and denitrfication.In:The nitrogen and sulphur cycles.Cambridege University Press, Cambridege, 1987: 161-218.

[2] Roberson L.A.etal.Nitrogen removal from water and waste.In:Microbial control of pollution.
[3] Kshirsagar M.Gupta A.B.Gupta S.K.Aerobic denitrification studies on activated sludge mixed with Thiosphaera pntotropha. APPL. Envir. Microbiol.

[4] Peng Yong ZHen, Wang Xiao Lian, Li Bai Kun.Anoxic biological phosphorus uptake and the effect of excessive aeration on biological phosphorus removal in the $\mathrm{A}_{2} \mathrm{O}$ process[J].Desalination,2006,189:155 164.

[5] Mulkerrins D., Dobson A. D. W. and Colleran E..Parameters affecting biological phosphate removal from wastewater[J]. Encvirnment International. 2004, 30: 249-259.

[6] Larose A,et.al.Respirometric control of the anaerobic period duration of an SBR Bio-P process. Wat.Sci.Tech., 2003, 36(5):293-300.

[7] Mulkerrins, A D W Dobson, E Colleran. Parameters affecting biological phosphate removal from wastewaters. Environment Intemational, 2004, 30: 249-259

[8] Xiaoling Wang, Yongzhen Peng, Yong Ma, Shuying Wang. Effects of operational varibles on nitrogen removal performances and its control in a pre-denitrification plant. Chme. Eng. Technol., 2007,30(2):234-241

[9] T. George, F. L. Burton, H. D. Stensel. Wastewater Engineering: Treatment Disposal and Reuse. Fourth edition. Metcalf and Eddy, Inc.McGraw-Hill,2000:287-290.

[10] Krishna C, van Loosdrecht MCM. Effect of temperature on storage polymers and settleability of activated sludge. Water Res 1999; 33(10): 2374-2382.

[11] Panswad T, Doungchai A, Anotai J. Temperature effect on microbial community of enhanced biological phosphrus removal system. Water Res 2003; 37(2): 409-415. 